\title{
PEMETAAN BEBERAPA CIRI KIMIA TANAH DI NAGARI SITIUNG KECAMATAN SITIUNG KABUPATEN DHARMASRAYA
}

\author{
Gunadi $^{1}$, Juniarti ${ }^{2}$, Gusnidar ${ }^{2}$ \\ ${ }^{1}$ Mahasiswa Pasca Sarjana Universitas Andalas \\ ${ }^{2}$ Program Studi Ilmu Tanah, Fakultas Pertanian, Universitas Andalas, Limau Manis, Padang. \\ Email: gun.adi1922@gmail.com
}

\begin{abstract}
Abstrak
Nagari Sitiung yang terletak di Kecamatan Sitiung Kabupaten Dharmasraya, Sumatera Barat memiliki luas 5804,3 ha, yang didominasi oleh perkebunan rakyat. Kandungan unsur kimia tanah di nagari Sitiung berkisar pada kriteria sangat rendah hingga sedang, namun belum ada informasi gambaran keadaan tanah dalam bentuk peta. Tujuan dari penelitian adalah untuk menentukan dan memetakan beberapa ciri kimia tanah Nagari Sitiung Kecamatan Sitiung Kabupaten Dharmasraya. Penelitian dilakukan dengan menggunakan metode survei, serta model analisis data spasial. Pengambilan sampel tanah berdasarkan satuan lahan (SL) yang dilakukan secara purposive random sampling.Ada 12 satuan lahan (SL) yang diambil yaitu: SL 1: Ultisols, lereng datar, kebun campuran; SL 2: Ultisols, lereng datar, sawah; SL 3: Entisols, lereng datar, sawah; SL 4: Entisols, lereng datar, kebun campuran; SL 5: Entisols, lereng landai, semak belukar; SL 6: Oxisols, lereng landai, semak belukar; SL 7: Entisols, lereng landai, kelapa sawit; SL 8: Entisols, lereng datar, kelapa sawit; SL 9: Oxisols, lereng landai, kelapa sawit; SL 10: Oxsisols, lereng datar, kelapa sawit; SL 11: Ultisols, lereng landai, kelapa sawit; SL 12: Oxsisols, lereng curam, kelapa sawit.Model analisis data dan spasial digunakan untuk pengolahan data hasil analisis tanah menjadi sebuah peta tematik pH tanah, Al-dd, C-organik, N-total, P-tersedia, KTK tanah, dan kation basa.Hasil penelitian menunjukkan nilai $\mathrm{pH}$ tertinggi 5,76 (agak masam) terdapat pada SL 3, dan nilai $\mathrm{pH}$ terendah 4,37 (sangat masam) terdapat pada SL 10. Nilai Al-dd tertinggi 9,72 me/100g terdapat pada SL 6, sedangkan nilai Al-dd terendah 0,92 me/100g terdapat pada SL 3. Selanjutnya, nilai Corganik tertinggi 3,12 \% (tinggi) terdapat pada SL 2, dan yang terendah 1,78 \% (rendah) pada SL 6. Kandungan N-total semuanya berada pada kriteria sedang. Kandungan P-tersedia tertinggi 14,7 ppm terdapat pada SL 10, dan yang terendah 7,93 ppm (rendah) terdapat pada SL 4. Nilai KTK tertinggi $12,74 \mathrm{me} / 100 \mathrm{~g}$ (rendah) terdapat pada SL 1, dan yang terendah 4,70 me/100g (sangat rendah) terdapat pada SL 7. Kandungan kation basa berada pada kriteria rendah sampai sedang.
\end{abstract}

Kata Kunci: Ciri Kimia Tanah, Nagari Sitiung, Peta Tanah Tematik, Satuan Lahan.

\begin{abstract}
Sitiung located in Dharmasraya, West Sumatera has 5804.3 haarea which was dominated by smallholder agriculture. The soil chemical properties in Sitiung village were often analysed by some scientists, but there was no map yet provided for the soil properties information. The purpose of the study was to determineand tocreate mapofsomesoil chemical characteristics in Sitiung Village, Sitiung District, Dharmasraya Regency. The study was conducted using a survey method, as well as spatial data analysis model. Soil sampling were taken in purposive random sampling under several land units (LU), the land units (LU) were limited by soil order, slopes, and land use. LU 1: Ultisols, flat, mixed garden; LU 2: Ultisols, flat, rice; LU 3: Entisols, flat, rice; LU 4: Entisols, flat, mixed garden; LU 5: Entisols, mild, shrubs; LU 6: Oxisols, mild, shrubs; LU 7: Entisols, mild, oil palm; LU 8: Entisols, flat, oil palm; LU 9: Oxisols, mild, oil palm; LU 10: Oxisols, flat, oil palm; LU 11: Ultisols, mild, oil palm; LU 12: Oxisols, steep, oil palm. Parameters analysed were pH, Alexchangable, organic-C, total-N, P-available, CEC, and base saturation. The spatial data analysis and data processing were used to transform soil analysis results into a thematic soil map.The result
\end{abstract}


showed that the highest $\mathrm{pH}$ value was 5.76 (slightly acid) found in LU 3, and the lowest $\mathrm{pH}$ value was 4.37 (highly acid) in LU 10. The highest Al-exchangable was $9.72 \mathrm{cmol} / \mathrm{kg}$ in LU 6, while the lowest value was $0.92 \mathrm{cmol} / \mathrm{kg}$ in LU3. Furthermore, the highest value oforganic-C was $3.12 \%$ (high) in LU 2, and the lowest was $1.78 \%$ (low) in the LU 6. The total-N content wasmedium. The highest content of P-available was $14.7 \mathrm{ppmin}$ LU 10, and the lowest was $7.93 \mathrm{ppm}$ (low) in the LU 4. The highest CEC was $12.74 \mathrm{cmol} / \mathrm{kg}$ (low) and the lowest was $4.70 \mathrm{cmol} / \mathrm{kg}$ (very low) in LU 7 . The basic cation content was found to be low to moderate.

Keyword: Land Unit, Sitiung Village, Soil chemical properties, Thematic soil map

(C) 2017 Gunadi Gunadi, Juniarti Juniarti, Gusnidar Gusnidar

\section{PENDAHULUAN}

Produktivitas tanah dipengaruhi oleh ketersediaan hara tanah yang sangat tergantung kepada sistem penggunaan lahan dan tipe penggunaan lahan di setiap daerah. Sistem penggunaan lahan mempengaruhi perbedaan ketersediaan hara tanah. Penggunaan lahan untuk tanaman semusim yang tidak ditambahkan bahan organik memiliki tingkat kesuburan tanah yang rendah, dibandingkan dengan penggunaan lahan tanaman tahunan.

Hal ini disebabkan tanaman semusim pengelolaan lahan dilakukan secara intensif sepanjang tahun. Akibatnya kandungan unsur hara akan terus berkurang sepanjang tahun. Tidak adanya rotasi tanaman dan pemberian bahan organik ke lahan tersebut akan membuat tanah semakin miskin unsur hara.

Gambaran keadaan tanah dapat dilihat dari hasil analisis unsur hara tanah. Informasi ini dapat disajikan dalam bentuk peta yang memuat berbagai informasi kesuburan tanah, sehingga dapat memudahkan penggunanya dalam penentuan dosis pupuk yang tepat bagi tanaman. Dengan dibuatnya peta beberapa ciri kimiatanah maka akan dapat diketahui kesuburan tanah pada suatu daerah. Selain penggunaan lahan, tingkat kesuburan tanah juga dipengaruhi oleh bahan induk dari tanah yang berada di lokasi tersebut. Tanah yang berasal dari bahan induk yang masam akan menghasilkan tanah yang kurang subur.

Nagari Sitiung merupakan salah satu nagari di Kecamatan Sitiung Kabupaten Dharmasraya, Sumatera Barat yang memiliki luas 5804,3 ha. Penggunaan lahan pada daerah ini didominasi oleh perkebunan kelapa sawit, sawah, dan kebun campuran. Berdasarkan penelitian Yanti (2011) pada tanah sawah di Sitiung I Blok D, didapatkan bahwa kandungan unsur kimia tanah di nagari tersebut berkisar pada kriteria sangat rendah hingga sedang, dimana nilai $\mathrm{pH}$ tanah. 6,24 (agak masam), Corganik $\quad 2,49 \% \quad$ (sedang), $\quad \mathrm{N}$-total $\quad 0,16 \%$ (rendah), P-tersedia 3,19 ppm (sangat rendah), K-dd 0,22 me/100 g (rendah), Ca-dd 0,86 me/100 g (sangat rendah), dan Mg-dd 0,29 me/100 g (sangat rendah). Namun, pada Nagari Sitiung belum ada informasi yang jelas mengenai gambaran keadaan tanahnya.

Menurut Peraturan Daerah Kabupaten Dharmasraya Nomor 10 tahun 2012 tentang Rencana Tata Ruang Wilayah Kabupaten Dharmasraya tahun 2011-2031, Nagari Sitiung telah dikembangkan menjadi kawasan budidaya yang didominasi oleh perkebunan rakyat dan persawahan dan akan lebih ditingkatkan lagi untuk masa yang akan datang. Untuk pengembangan wilayah disektor pertanian maka sangat penting dilakukan penelitian

Tujuan dari penelitian ini adalah untuk untuk menentukan dan memetakan beberapa ciri kimia tanah Nagari Sitiung Kecamatan Sitiung Kabupaten Dharmasraya

\section{BAHAN DAN METODA}

Penelitian dilakukan dengan menggunakan metode survei, serta model analisis data spasial. Pengambilan sampel tanah dilakukan berdasarkan perbedaan masing-masing satuan lahan. Sedangkan model analisis data dan spasial yang digunakan untuk pengolahan data dengan menggunakan software QGis versi 2.10.1, dan SAS Planet. 


\section{Pelaksanaan Penelitian}

\section{Tahap Persiapan (pengumpulan data)}

Data primer meliputi data lingkungan tanah dan data karakteristik tanah yang diperoleh berdasarkan hasil survei lapangan. Sedangkan data sekunder berupa data spasial yang berbentuk peta yang diperlukan dalam penelitian yang diperoleh dari lembaga yang berwenang mengeluarkan peta.

\section{Pra Survei}

Pada tahap ini dilakukan penentuan titik pengamatan di lapangan berdasarkan peta satuan lahan lokasi penelitian untuk mengetahui gambaran daerah penelitian, dan analisa peta untuk penentuan lokasi penelitian serta pembuatan peta pengambilan titik sampel. Pada tahap ini juga ditentukan lokasi pengambilan sampel melalui pemboran tanah dan pengamatan terhadap kondisi fisik lingkungan seperti bentuk wilayah, kelerengan, penggunaan lahan, vegetasi dan lain-lain.

\section{Tahap Survei Utama dan Pengambilan} Sampel

Pada tahap survei utama dilakukan untuk verifikasi hasil interpretasi satuan lahan di lapangan dan pengambilan sampel tanah, yaitu meliputi :

1) Pengamatan kondisi fisik lahan

Pengamatan keadaan lingkungan dilakukan melalui interpretasi peta satuan lahan dan peta penggunaan lahan, yaitu mengamati tanda-tanda alam seperti jalan setapak, jalur aliran sungai, rawa, perbukitan dan batas daerah survei sesuai dengan keadaan fisiografi wilayah dan penggunaan lahan sekarang

2) Pengambilan sampel tanah

Pengambilan sampel tanah dilakukan berdasarkan satuan lahan dengan 12 satuan lahan. Sampel tanah diambil pada kedalaman $0-20 \mathrm{~cm}$ sehingga dapat diketahui tingkat kesuburan tanah. Teknik pengambilan sampel tanah dilakukan secara purposive random sampling menggunakan bor. Dimana setiap satuan lahan diambil sebanyak 5 titik pemboran, kemudian sampel tanah dikompositkan.

Sampel tanah dibawa ke laboratorium untuk terlebih dahulu dikering anginkan, kemudian dihaluskan dan selanjutnya dianalisis di laboratorium.

\section{Analisis di Laboratorium}

Analisis tanah di laboratorium meliputi analisis sifat kimia tanah. Adapun analisis tanah yang dilakukan meliputi :

1. Penetapan $\mathrm{pH}$ tanah dengan $\mathrm{H}_{2} \mathrm{O}$ dan $\mathrm{KCl}$ (1:5) dengan metoda Elektroda gelas $\mathrm{pH}$ meter,

2. Penetapan C-Organik dengan metoda Walkley dan Black

3. Penetapan Kapasitas Tukar Kation (KTK) dengan metoda pencucian Ammonium Asetat $1 \mathrm{~N} \mathrm{pH} 7$

4. Penetapan P-tersedia dengan metoda Bray-II

5. Penetapan N-total dengan metode Kjeldahl

6. Penetapan basa-basa dapat dipertukarkan $(\mathrm{Ca}, \mathrm{Mg}, \mathrm{K}$, dan $\mathrm{Na})$ dengan metoda pencucian Ammonium Asetat $1 \mathrm{~N}$ pH 7

7. Penetapan Al-dd dengan metoda Volumetri

\section{Pembuatan Peta Hasil Penelitian}

\section{Penyusunan Basis Data}

a. Data Primer

Data primer berupa data karakteristik tanah yaitu data $\mathrm{pH}$ tanah, KTK tanah, kandungan C-organik, P-tersedia, N-total, Kejenuhan Basa, dan Al-dd tanah yang diperoleh dari hasil analisis laboratorium yang telah dilakukan.

\section{b. Data Sekunder}

Adapun data sekunder yang dimaksud adalah :

1) Peta Administrasi Daerah Penelitian, Kenagarian Sitiung, Kecamatan Sitiung, Kabupaten Dharmasraya, Sumatera Barat yang berasal dari BPS tahun 2010.

2) Peta Topografi hasil pengolahan data SRTM 57-13.

3) Peta Kelas Lereng hasil pengolahan data SRTM 57-13.

4) Peta Geologi lembar Solok (0815) dan lembar Painan (0814) skala 1:250.000 tahun 1996.

5) Peta Satuan Lahan dan Tanah Sumatera Barat Lembar Solok (0815) dan lembar 
Painan (0814) tahun 1990 serta Buku Keterangan Peta satuan Lahan dan Tanah Lembar Solok (0815) dan lembar Painan (0814), Sumatera. Pusat Penelitian Tanah dan Agroklimat Bogor Skala 1:250.000 tahun 1990.
6) Peta satuan lahan yang merupakan hasil overlay dari peta administrasi, peta tanah, peta kelas lereng, dan peta penggunaan lahan.

\section{Pembuatan Peta Digital}

Langkah pembuatan peta tematik unsur hara tanah dapat dilihat pada gambar 1 .

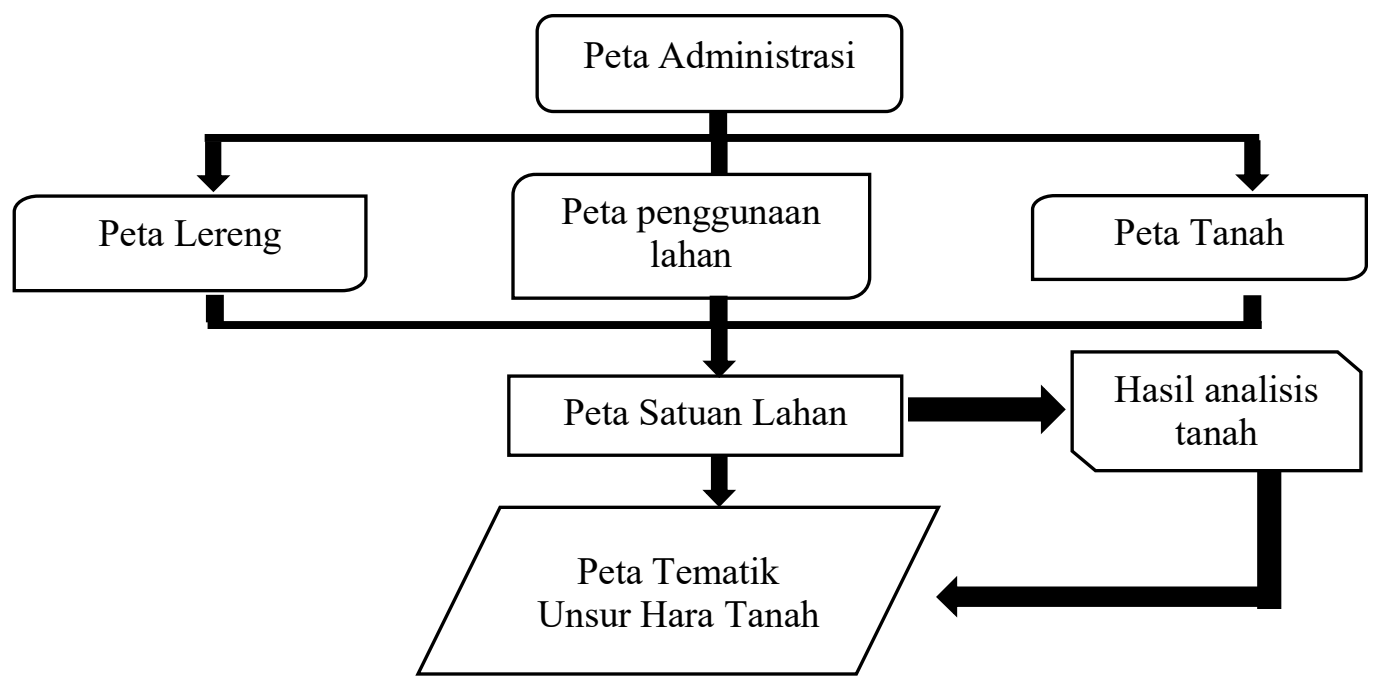

Gambar 1. Pembuatan Peta Tematik Unsur Hara Tanah

\section{HASIL DAN PEMBAHASAN}

\section{A. Keadaan Umum Wilayah Penelitian}

Secara administratif daerah penelitian terletak pada nagari Sitiung Kecamatan Sitiung, Kabupaten Dharmasraya, Provinsi Sumatera Barat dengan luas areal 5804,3 ha. Posisi geografis nagari Sitiung terletak pada 101'35'3,917'-101'41'28,748" BT dan 0 $56^{\prime} 7,355^{\prime \prime}-1^{\circ} 2^{\prime} 1,99$ ' LS, dengan ketinggian tempat berkisar antara 100- $315 \mathrm{mdpl}$. Sebelah Utara nagari Sitiung berbatasan dengan nagari Panyubarangan, sebelah Selatan nagari Gunung Medan, Sebelah Barat nagari Siguntur, dan sebelah Timur nagari Sungai Duo.

Daerah penelitian memiliki 3 jenis kelas lereng yang diperoleh dari hasil pengolahan data Shuttle Radar Topographic Mission (SRTM) 57-13 kemudian dicocokkan dengan pengamatan di lapangan. Daerah penelitian tersebar pada topografi datar $(0-8 \%)$ dengan luas 3210,51 ha, landai (8-15\%) dengan luas 1867,22 ha, dan curam (>40\%) dengan luas 732,65 ha.

\section{B. Kondisi Iklim}

Berdasarkan data pada Tabel 3, terlihat bahwa rata-rata curah hujan bulanan nagari Sitiung berkisar antara 60,27-217,50 mm. Pada daerah penelitian tidak ada bulan kering karena curah hujan terendah $60,27 \mathrm{~mm}$. Bulan-bulan lembap terdapat pada Januari, Juni, Juli, September, dan Oktober, dengan curah hujan berkisar antara 60,27-99,14 $\mathrm{mm}$ (rata-rata curah hujan bulan lembab 80,9 mm). Bulanbulan basah terdapat pada Februari, Maret, April, Mei, Agustus, November, dan Desember dengan curah hujan berkisar antara 103,68$163,12 \mathrm{~mm}$ (rata-rata curah hujan bulan basah $255,16 \mathrm{~mm})$.

Schmidt dan Ferguson (1951) membagi iklim sebagai berikut: bulan kering bila curah hujan $<60 \mathrm{~mm} /$ bulan, bulan lembab bila curah hujan 60-100 mm/bulan, dan bulan basah bila curah hujan $>100 \mathrm{~mm} /$ bulan. Berdasarkan perhitungan klasifikasi iklim menurut Schmidt dan Ferguson (1951) didapatkan nilai $\mathrm{Q}=0,00$ $\mathrm{mm}$. Dengan demikian, nagari Sitiung Kecamatan Sitiung Kabupaten Dharmasraya 
termasuk ke dalam tipe Iklim A dengan kondisi sangat basah karena tidak ada bulan kering.

\section{Penggunaan Lahan}

Berdasarkan kenampakan citra satelit Google Satelite tahun 2014, daerah penelitian ini memiliki 5 macam penggunaan lahan yaitu pemukiman dengan luas 392,506 ha, sawah dengan luas 1171,08 ha, kebun campuran dengan luas $\quad 1152,52$ ha, perkebunan kelapa sawit dengan luas 1831,27 ha, dan semak belukar dengan luas 1257,01 ha. Semak Belukar pada lokasi penelitian merupakan lahan bekas hutan yang telah ditebang, karena hutan pada daerah penelitian ini pada tahun 2010 mulai banyak dibuka oleh masyarakat untuk diambil kayunya.

Perkebunan kelapa sawit merupakan penggunaan lahan yang paling luas di kecamatan Sitiung mencapai 5542 ha (BPS, 2016). Untuk nagari Sitiung mencapai 33,04\% dari luas perkebunan di kecamatan tersebut yang produksinya terus bertambah setiap tahunnya. Kelapa sawit menjadi tanaman yang sangat diandalkan masyarakat dalam memenuhi kebutuhan hidupnya. Hal ini ditunjukkan dengan maraknya alih fungsi lahan kebun campuran menjadi kelapa sawit. Tanaman kelapa sawit pada lokasi penelitian sudah mulai ditanam sejak tahun 1996 dan sampai sekarang masih banyak masyarakat yang menambah luas tanaman. Pupuk yang diberikan pada lahan sawit berupa pupuk kimia buatan seperti NPK, Urea, SP36, KCl, dan lainlain yang diberikan setiap 6 bulan, dengan takaran pupuk NPK per batang kira-kira 1-1,5 $\mathrm{kg} ; \mathrm{KCl} 1,5-2 \mathrm{~kg} ; \mathrm{SP} 36$ 1,5-2 kg. Setiap pemberian pupuk pada tanaman kelapa sawit petani tidak memiliki pedoman, sehingga pupuk yang diberikan berbeda-beda setiap petani. Untuk pengendalian gulma, petani menggunakan herbisida seperti Roundup, Gramoxone, Gramakuat, Ally, dan lain-lain. Alasannya herbisida untuk pengendalian gulma lebih praktis dan dapat menghemat waktu.

Kebun campuran pada daerah penelitian ini merupakan tanah yang berada di sekitar pemukiman yang ditanami dengan berbagai macam tanaman tahunan seperti jeruk siam (Citrusnobilis), karet (Heveabraziliensis), kakao (Theobromacacao), rambutan (Napheliumlappaceum), durian (Duriozibethinus) dan duku (Lansiumdomesticum). Selain tanaman tahunan, masyarakat juga menanam tanaman semusim seperti pisang (Musa paradisiaca), jagung (Zeamays), kacang tanah (Arachishypogaea L.), dan ubi kayu (Manihotutilisima). Pada kebun campuran tidak ada pemberian pupuk, sehingga sumber unsur hara tanahnya hanya berasal dari serasah dan sisa tanaman yang telah melapuk.

Lahan sawah pada daerah penelitian pada awalnya merupakan sawah tadah hujan, kemudian pada tahun 1996-2006 mulai dibangun saluran irigasi Batang Hari dan tahun 2008 masyarakat sudah dapat memanfaatkan saluran irigasi sebagai sumber air untuk sawah (Litbang Pertanian, 2010). Dengan adanya saluran irigasi teknis yang berasal dari sungai Batang Hari maka masyarakat dapat menanam padi sebanyak 3 kali dalam setahun, sehingga pengolahan lahannya menjadi sangat intensif. Pengolahan tanah sawah dilakukan secara mekanis menggunakan handtractor. Sisa panen berupa jerami padi dikumpulkan pada satu tempat kemudian dibakar hingga menjadi abu. Pada lahan sawah tidak ada rotasi tanaman, karena sumber air selalu mencukupi untuk menanam padi sepanjang tahun. Pupuk yang digunakan berupa pupuk kimia buatan seperti NPK, urea, TSP, KCl, Phonska, dan lain-lain. Pemberian pupuk dilakukan sebanyak 3 kali, yaitu tahap pertama pada saat padi berumur 2 minggu dipupuk menggunakan Urea $100 \mathrm{~kg} / \mathrm{ha}$ dan TSP $50 \mathrm{~kg} / \mathrm{ha}$, kemudian pemberian pupuk tahap kedua dilakukan pada saat padi berumur 25-30 hari menggunakan pupuk Urea $50 \mathrm{~kg} / \mathrm{ha}$ dan Phonska $100 \mathrm{~kg} / \mathrm{ha}$, dan pemberian pupuk tahap ke tiga diberikan pada saat padi berumur 40-45 hari menggunakan pupuk urea sebanyak $50 \mathrm{~kg} / \mathrm{ha}$.

\section{Karakteristik Lahan}

Gambaran tentang fisiografi daerah penelitian dapat dilihat berdasarkan peta satuan lahan dan tanah lembar Painan (0814) serta Lembar Solok (0815) skala 1:25.000 yang dikeluarkan dari Pusat Penelitian Tanah dan Agroklimat tahun 1990 yang kemudian 
dilakukan pengamatan di lapangan sehingga diperoleh 4 jenis satuan fisiografi yaitu; (a) Dataran banjir dari sungai yang bermeander, (b) Teras sungai, (c) Perbukitan kecil dengan pola random, dan (d) Pegunungan.

Terdapat 3 jenis tanah pada tingkat Great Group yaitu; (a) Tropofluvents yang terdapat pada fisiografi dataran banjir dengan luas 1880,12 ha, (b) Paleudultsyang terdapat pada fisiografi teras sungai, perbukitan kecil dengan pola random, dan pegunungan dengan luas 2593,86 ha, dan (c) Hapludox yang terdapat pada fisiografi perbukitan kecil dengan pola random dengan luas 1336,39 ha.

Berdasarkan peta geologi lembar Painan (0814) dan Lembar Solok (0815) skala 1:25.000 yang dipublikasikan oleh Pusat Penelitian dan Pengembangan Geologi (1996) dijelaskan bahwa terdapat 3 jenis litologi yaitu; (a) endapan permukaan (alluvium; lanau, pasir, dan kerikil), (b) batuan metamorf (anggota filit dan serpih formasi Kuantan; serpih dan filit, sisipan batu sabak, kuarsit, batu lanau, rijang, dan aliran lava), dan (c) batuan intrusi (granit; susunannya berkisar dari leuco-granit sampai monzonite kuarsa).

\section{Hasil Analisis Ciri Kimia Tanah}

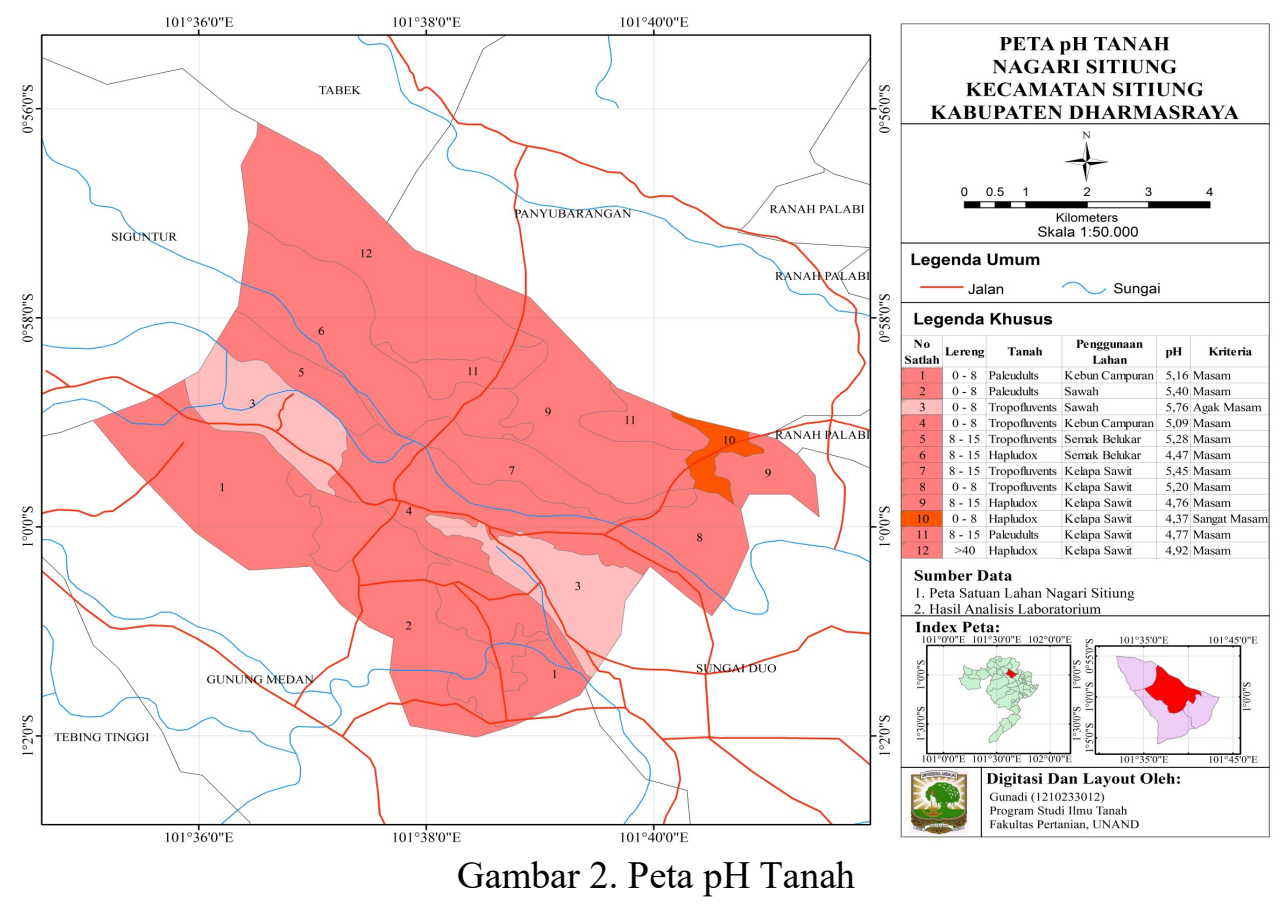




\section{Al-dd Tanah}

Aluminium merupakan unsur toksik yang dapat mengganggu penyerapan unsur hara maupun pertumbuhan tanaman. Toksisitas Al merupakan konsekuensi tingginya kejenuhan $\mathrm{Al}$ dalam tanah masam. Pengaruh keracunan $\mathrm{Al}$ terutama membatasi kedalaman maupun percabangan akar, sehingga akan menghambat daya serap tanaman terhadap hara lain (Hanafiah, 2005). Hasil analisis Al-dd tanah dapat dilihat pada Gambar 3.

Berdasarkan Gambar 3, dapat dilihat bahwa pada satuan lahan 1 dengan penggunaan lahan kebun campuran di Ultisol pada lereng datar mempunyai kandungan Al-dd 1,86 me/100 g. Hal ini disebabkan karena kandungan Al-ddnya sangat rendah karena dipengaruhi oleh nilai $\mathrm{pH}$ tanah yang agak masam. Pada kondisi masam, Al akan tertarik keluar struktur liat dan menduduki muatanmuatan negatif kosong tersebut. Al dapat ditukar (Al-dd) ini diadsorbsi sangat kuat oleh koloid, tetapi berada dalam keseimbangandengan ion-ion $\mathrm{Al}^{3+}$ dalam larutan tanah. Hidrolisis Al ini akan menghasilkan Al-hidroksida dan ion-ion $\mathrm{H}^{+}$.
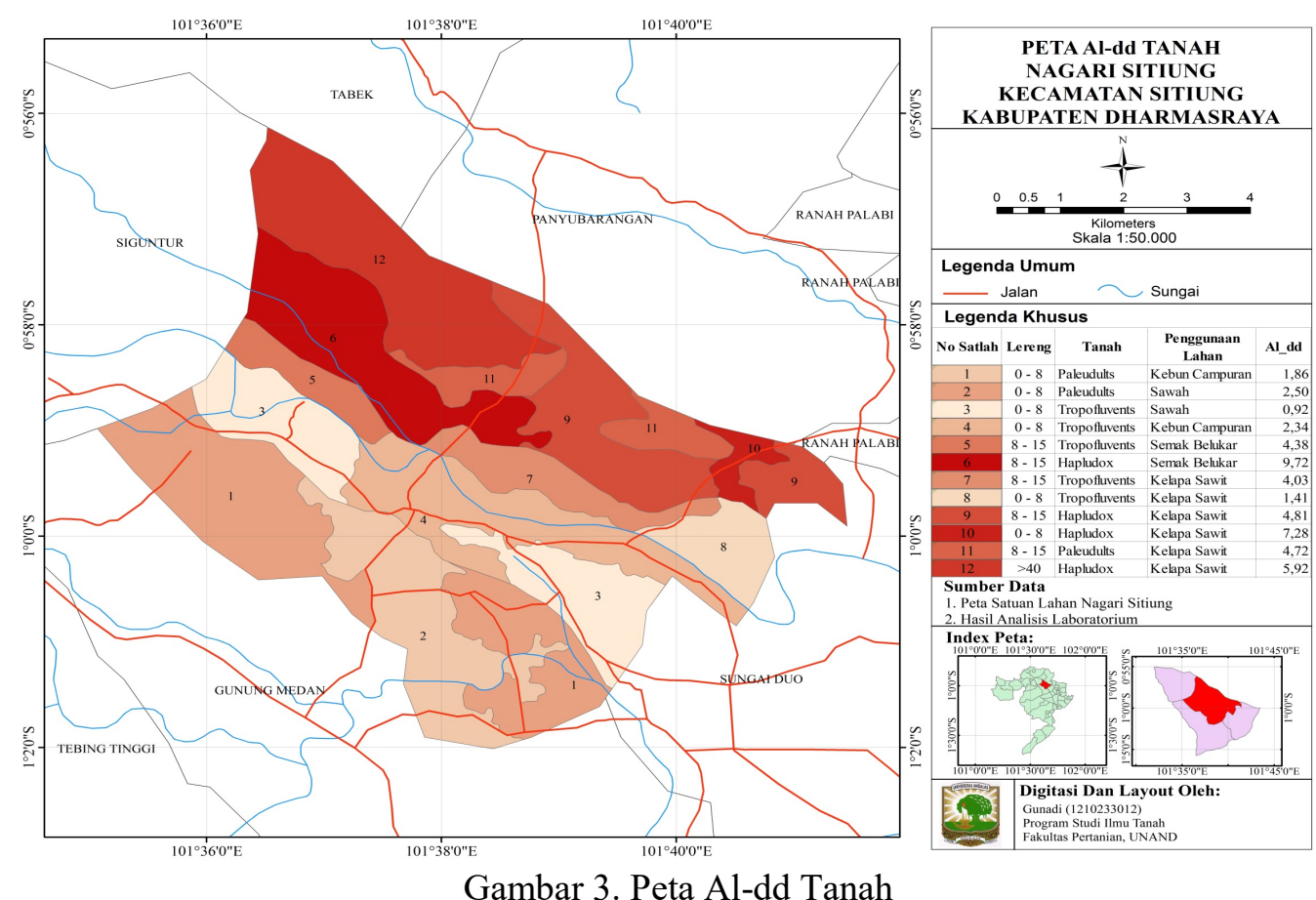

Gambar 3. Peta Al-dd Tanah

\section{C-organik tanah}

Pada Gambar 4 dapat dilihat bahwa pada umumnya kandungan C-organik pada daerah penelitian berada pada kriteria sedang, hal ini disebabkan karena adanya sumbangan bahan organik yang berasal dari serasah dan tanaman penutup tanah.

Kandungan C-organik rendah terdapat pada satuan lahan 6 dengan penggunaan lahan kebun campuran di Oxsisols pada lereng datar, satuan lahan 7 dengan penggunaan lahan hutan di Entisols pada lereng landai, hal ini diduga karena cepatnya proses dekomposisi bahan organik karena curah hujan yang tinggi. Pada satuan lahan 6 rendahnya kandungan C-organik tanah disebabkan karena semak belukar ini tumbuh setelah hutan ditebang yang menyebabkan terjadinya erosi tanah yang mengikis tanah lapisan atas. Hal ini sesuai dengan pernyataan Luki (1999) yang menyatakan bahwa alih fungsi lahan hutan ke berbagai penggunaan lahan telah menyebabkan terjadinya penurunan kandungan bahan organik tanah. Setelah hutan dibuka, bahan organik tanah mengalami penurunan pada beberapa penggunaan lahan. 
Kandungan C-organik tinggi terdapat pada satuan lahan 2 dengan penggunaan lahan sawah di tanah Ultisols pada lereng datar. Hal ini disebabkan karena pada lahan sawah ini terdapat pengembalian bahan organik berupa sisa jerami padi yang ikut terolah pada saat penyiapan lahan. Menurut Winarso (2003) jerami padi mempunyai kandungan $\mathrm{C} / \mathrm{N}$ yang tinggi yaitu di atas 40 .

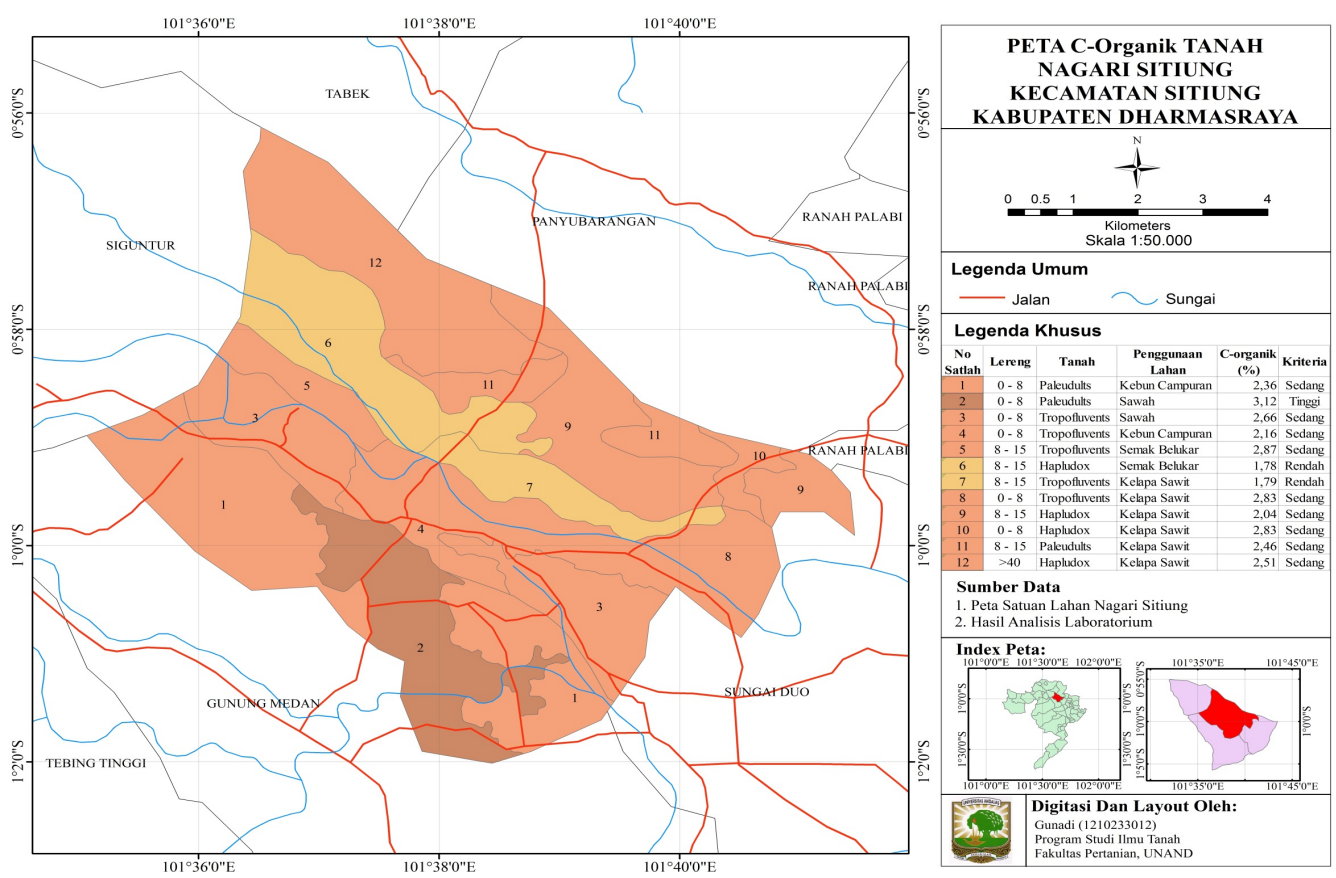

Gambar 4. Peta C-organik Tanah

\section{N-total tanah}

Berdasarkan Gambar 5, dapat diketahui bahwa daerah penelitian memiliki kandungan $\mathrm{N}$-total tanah yang berada pada kriteria sedang yang berkisar antara 0,21-0,47\%. Unsur $\mathrm{N}$ di dalam tanah berasal dari hasil dekomposisi bahan organik sisa-sisa tanaman maupun binatang, pemupukan (terutama urea dan ammonium nitrat), dan air hujan (Hanafiah, 2005). Selain itu, kandungan $\mathrm{N}$ di dalam tanah juga dipengaruhi oleh aktivitas mikroorganisme di dalam tanah.

Pada lahan sawah sumbangan $\mathrm{N}$ ke dalam tanah berasal dari pemupukan dan juga dari sisa tanaman padi yang melapuk. Pada kelapa sawit, kandungan $\mathrm{N}$ berasal dari pemupukan dan juga pelapukan daun dan pelepah sawit. Sedangkan pada kebun campuran dan semak belukar sumber $\mathrm{N}$ berasal serasah tanaman. Foth (1998) menyatakan bahwa peningkatan kandungan $\mathrm{N}$ tanah untuk tanaman terdiri dari meningkatnya jumlah penambahan pupuk N.

Kehilangan $\mathrm{N}$ dari dalam tanah disebabkan karena erosi, pencucian dan terikat oleh mikroba dekomposer. Selain itu, kehilangan $\mathrm{N}$ juga dapat terjadi akibat denitrifikasi yaitu konversi bentuk nitrogen organik tanah menjadi gas nitrogen $\left(\mathrm{N}_{2}\right)$ (Utomo et al., 2016).

\section{P-tersedia}

Berdasarkan Gambar 7, dapat dilihat bahwa pada umumnya kandungan P-tersedia di daerah penelitian berada pada kriteria rendah. Hal ini diduga karena adanya hubungan antara $\mathrm{pH}$ tanah dengan kandungan P-tersedia tanah karena $\mathrm{pH}$ tanah di daerah penelitian ini berada pada $\mathrm{pH}$ sangat masam, masam, dan agak masam. Hal ini sesuai dengan pendapat Hanafiah (2005) yang menyatakan bahwa ketersediaan $\mathrm{P}$ optimum pada kisaran $\mathrm{pH}$ 6,0 - 
7,0. Ketersediaan $\mathrm{P}$ bagi tanaman terutama disebabkan karena pada $\mathrm{Ph}$ di bawah 5,6, kelarutan $\mathrm{Fe}$ (hara makro toksik) dan $\mathrm{Al}$ (unsur toksik) meningkat sehingga memfiksasi dan mengendapkan P larutan membentuk Al-P dan Fe-P. pada daerah penelitian ini juga memiliki jenis tanah yang sudah mengalami pelapukan lanjut yaitu tanah Ultisols dan Oxsisols.
Pada satuan lahan 10 dengan penggunaan lahan kelapa sawit di tanah Oxsisols pada lereng datar memiliki kandungan P-tersedia sedang sedangkan $\mathrm{pH}$ tanahnya sangat masam. Hal ini diduga karena adanya penambahan fosfor ke dalam tanah melalui pemupukan.

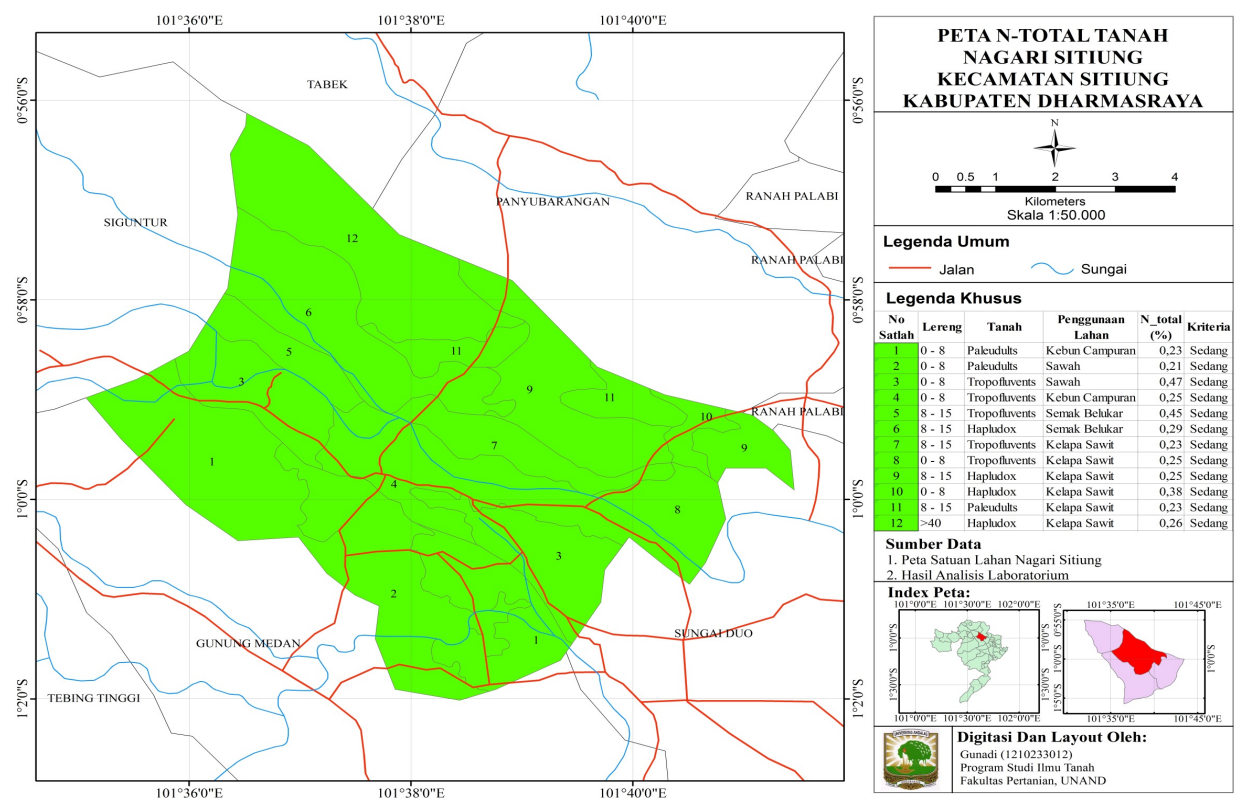

Gambar 5. Peta N-Total tanah.

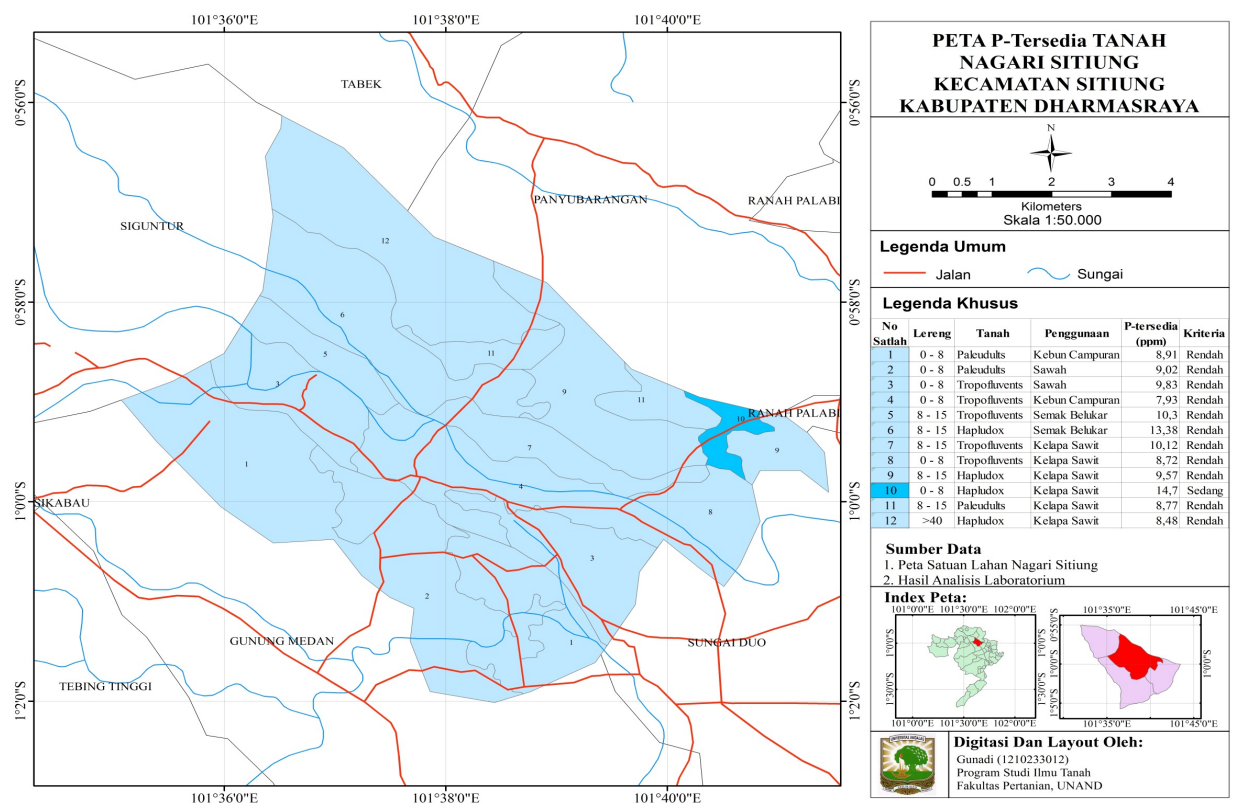

Gambar 6 Peta P-Tersedia Tanah 


\section{Kapasitas Tukar Kation (KTK)}

Berdasarkan Gambar 8, dapat dilihat bahwa pada umumnya kandungan KTK tanah pada daerah penelitian berada pada kriteria rendah dan sangat rendah. Hal ini diduga karena berhubungan dengan $\mathrm{pH}$ tanah di daerah penelitian yang umumnya pada kriteria sangat masam, masam dan agak masam serta memiliki kandungan bahan organik yang berada pada kriteria rendah, dan sedang. Menurut Hardjowigeno (2003) besar kecilnya nilai KTK tanah dipengaruhi oleh beberapa faktor yaitu reaksi tanah $(\mathrm{pH})$, jumlah liat (tekstur tanah), jenis mineral liat, jumlah bahan organik, pengapuran, dan pemupukan.

KTK tanah pada satuan lahan 7 dengan penggunaan lahan kelapa sawit di Entisols pada lereng landau berada pada kriteria sangat rendah. Hal ini disebabkan karena curah hujan didaerah penelitian yang tinggi dan berada pada lereng landai sehingga menyebabkan pencucian unsur hara sangat intensif, selain itu $\mathrm{pH}$ tanah yang masam juga dapat mempengaruhi nilai KTK tanah. Pada $\mathrm{pH}$ muatan negatif atau muatan tergantung $\mathrm{pH}$ muatannya rendah pada $\mathrm{pH}$ masam dan pada pH basa akan tinggi muatannya (Salam, 2012). Tanah dengan KTK tinggi mampu menyerap dan menyediakan unsur hara yang lebih baik daripada tanah dengan KTK rendah, karena unsur-unsur hara terdapat dalam kompleks jerapan koloid maka unsur hara tidak mudah hilang tercuci oleh air (Soewandita, 2008).

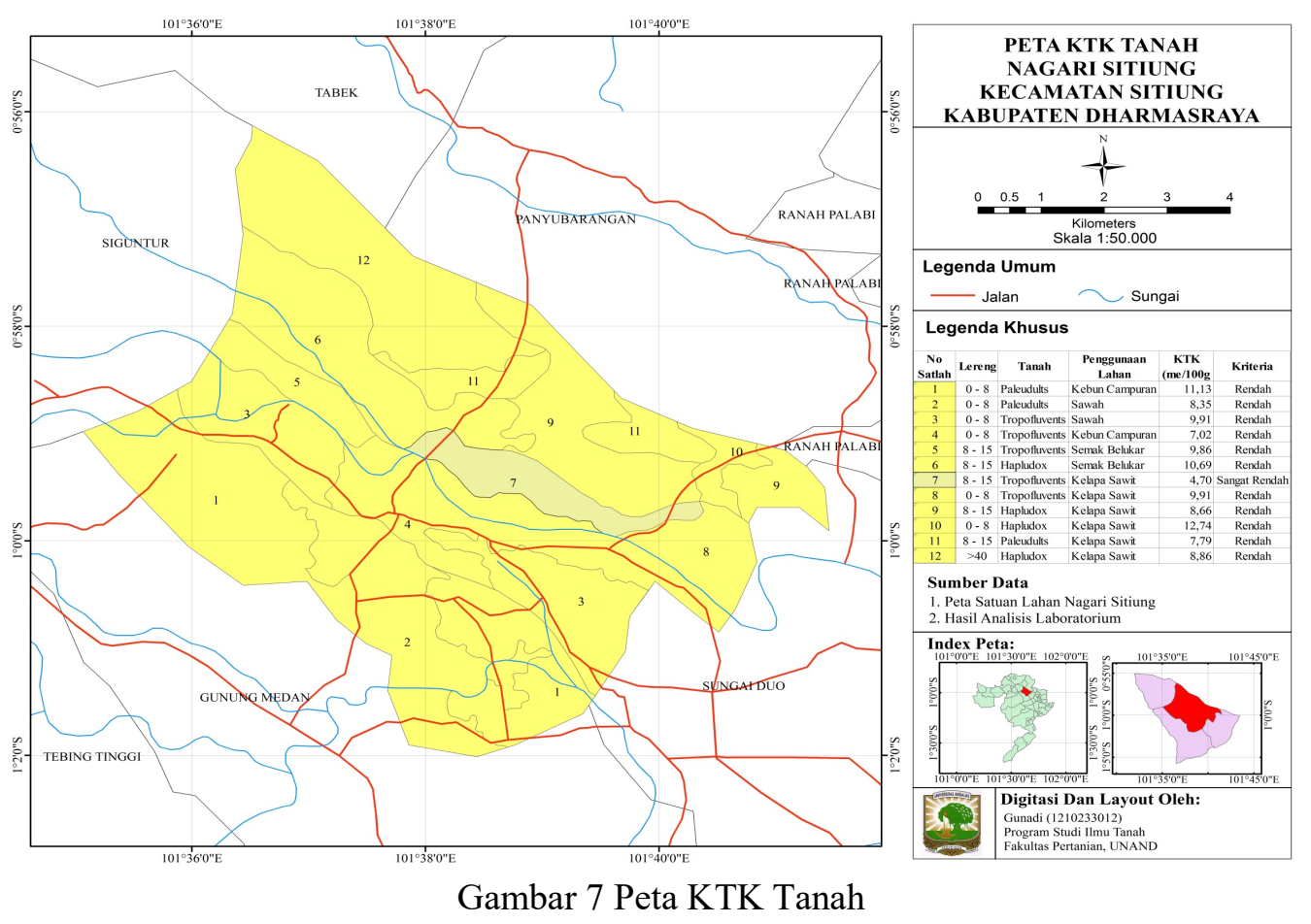

\section{Kation Basa}

Berdasarkan Gambar 9, dapat dilihat bahwa kandungan Kalium (K) dan Natrium (Na) di daerah penelitian berada pada kriteria sangat rendah. Hal ini disebabkan karena curah hujan di daerah penelitian yang cukup tinggi sehingga $\mathrm{K}$ akan tercuci. Menurut Hanafiah (2005) unsur K mudah mengalami pencucian dari tanah, keadaan ini menyebabkan ketersediaan unsur ini dalam tanah umumnya rendah dibanding basa-basa lain. Sedangkan $\mathrm{Na}$ banyak ditemukan pada daerah beriklim arid dan semi-arid yang berperan penting dalam menentukan karakteristik tanah dan pertumbuhan tanaman.

Kandungan kalsium (Ca) di daerah penelitian berada pada kriteria redah dan sedang. Hal ini disebabkan karena daerah 
penelitian ini juga memiliki $\mathrm{pH}$ tanah yang masam. Ketersediaan unsur $\mathrm{Ca}$ akan tinggi pada $\mathrm{pH} 7,0-8,5$, kemudian menurun pada $\mathrm{pH}$ di bawah 7,0 maupun di atas 8,5. Akan tetapi kandungan $\mathrm{Ca}$ di dalam tanah umumnya selalu lebih tinggi dibanding Mg (Hanafiah, 2005).

Kandungan Magnesium (Mg) berada pada kriteria rendah karena disebabkan $\mathrm{pH}$ tanah yang juga masam. Hal ini sesuai pernyataan Utomo et al., (2016) yang menyatakan bahwa hasil analisis $\mathrm{Mg}$ tanah didapat rendah pada tanah yang $\mathrm{pH}$-nya rendah. Pengaruh iklim juga berpengaruh terhadap ketersediaan $\mathrm{Mg}$ di dalam tanah, karena keterikatan $\mathrm{Mg}$ pada situs pertukaran kation lebih lemah, sehingga kehilangan lewat pelindian dan defisiensi $\mathrm{Mg}$ lebih sering menjadi masalah (Hanafiah, 2005).

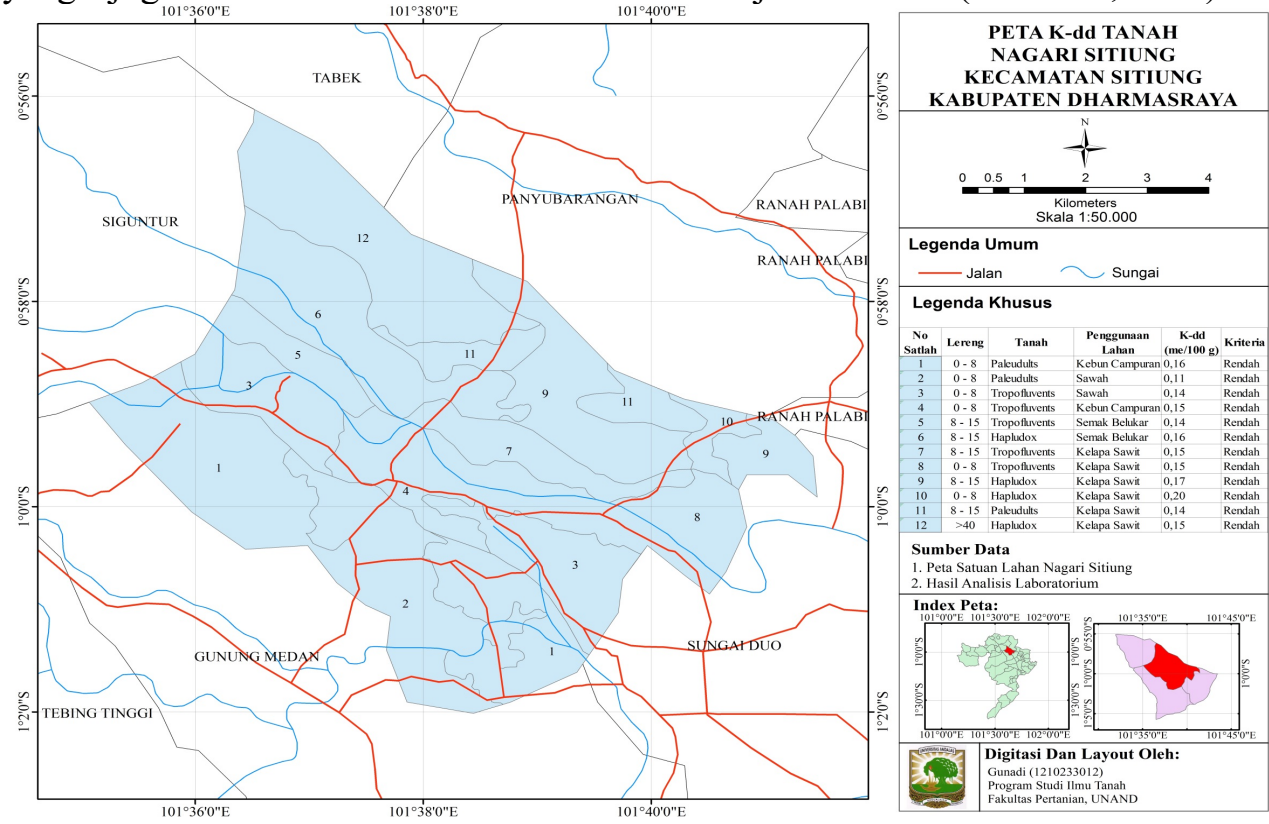

Gambar 8. Peta K-dd Tanah

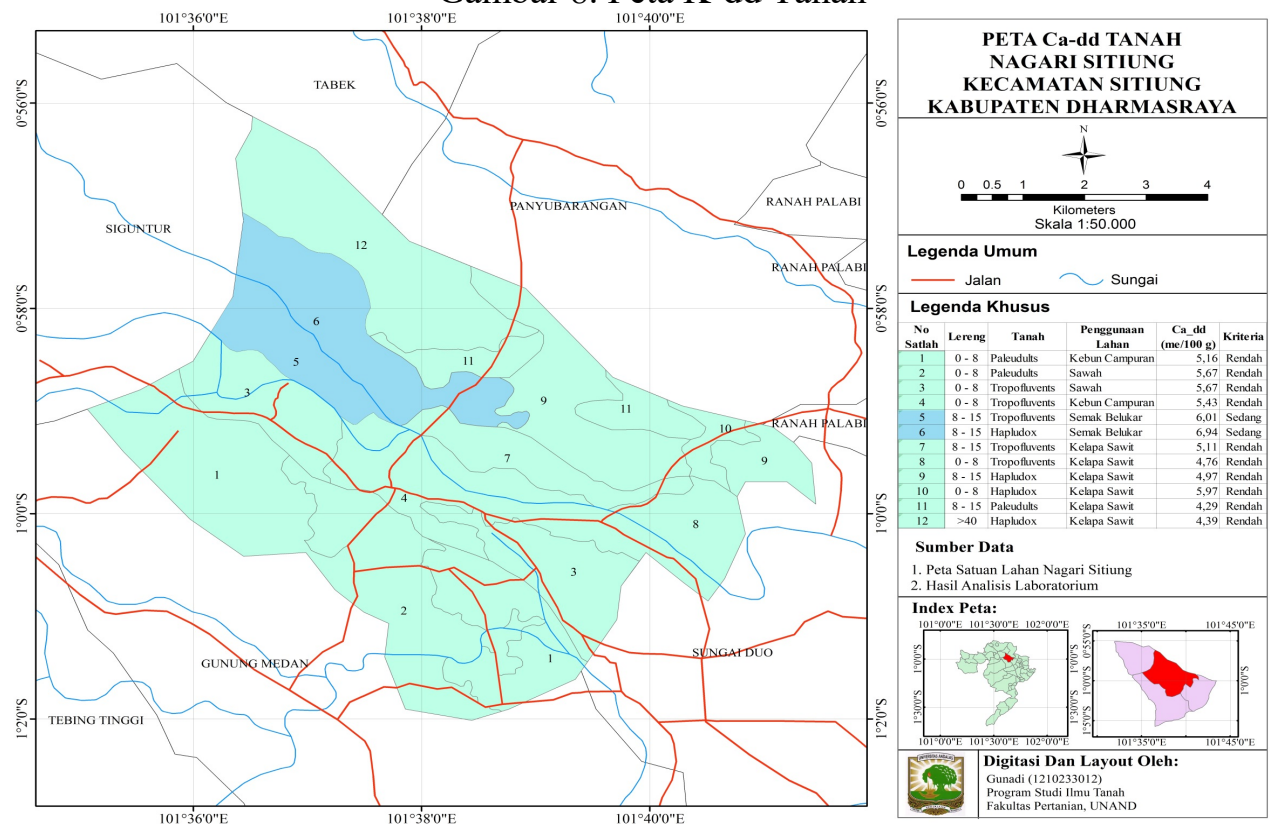

Gambar 9. Peta Ca-dd Tanah. 

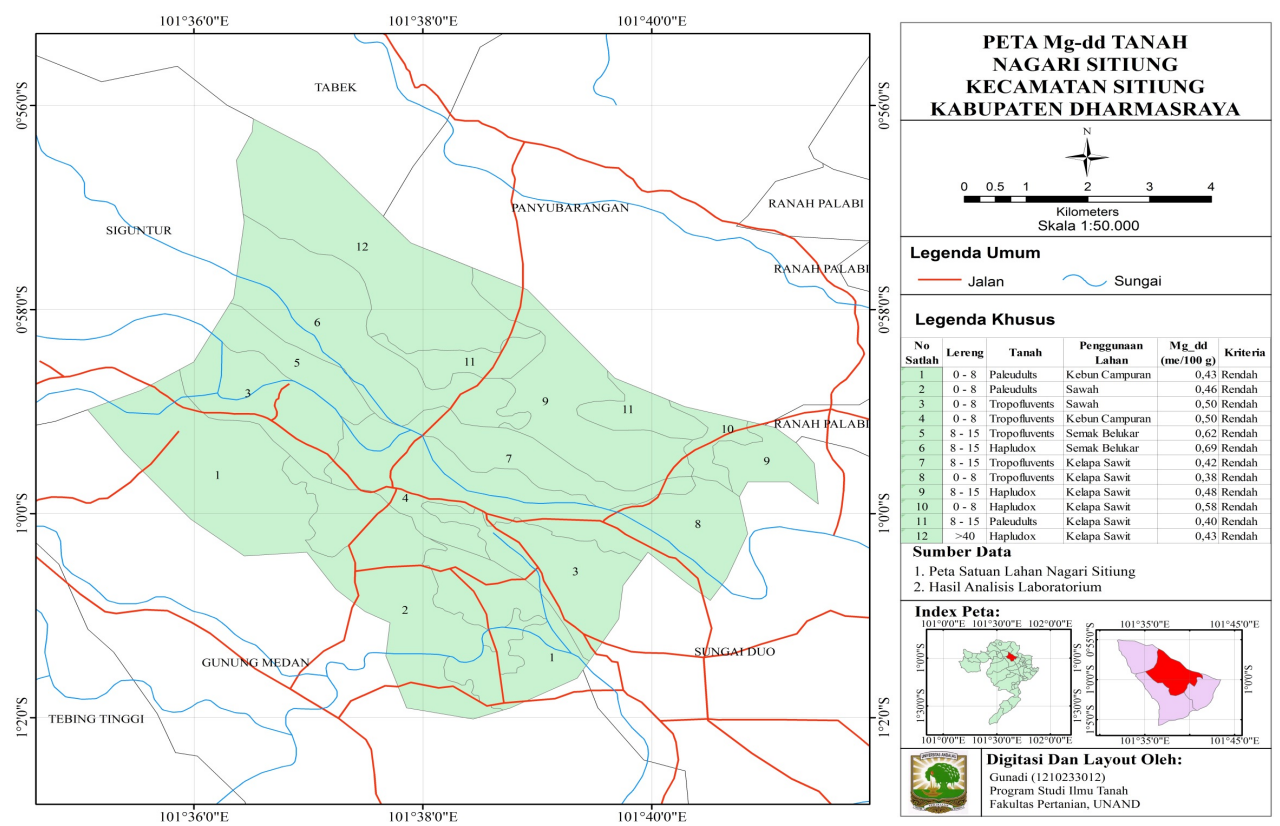

Gambar 10. Peta Mg-dd Tanah
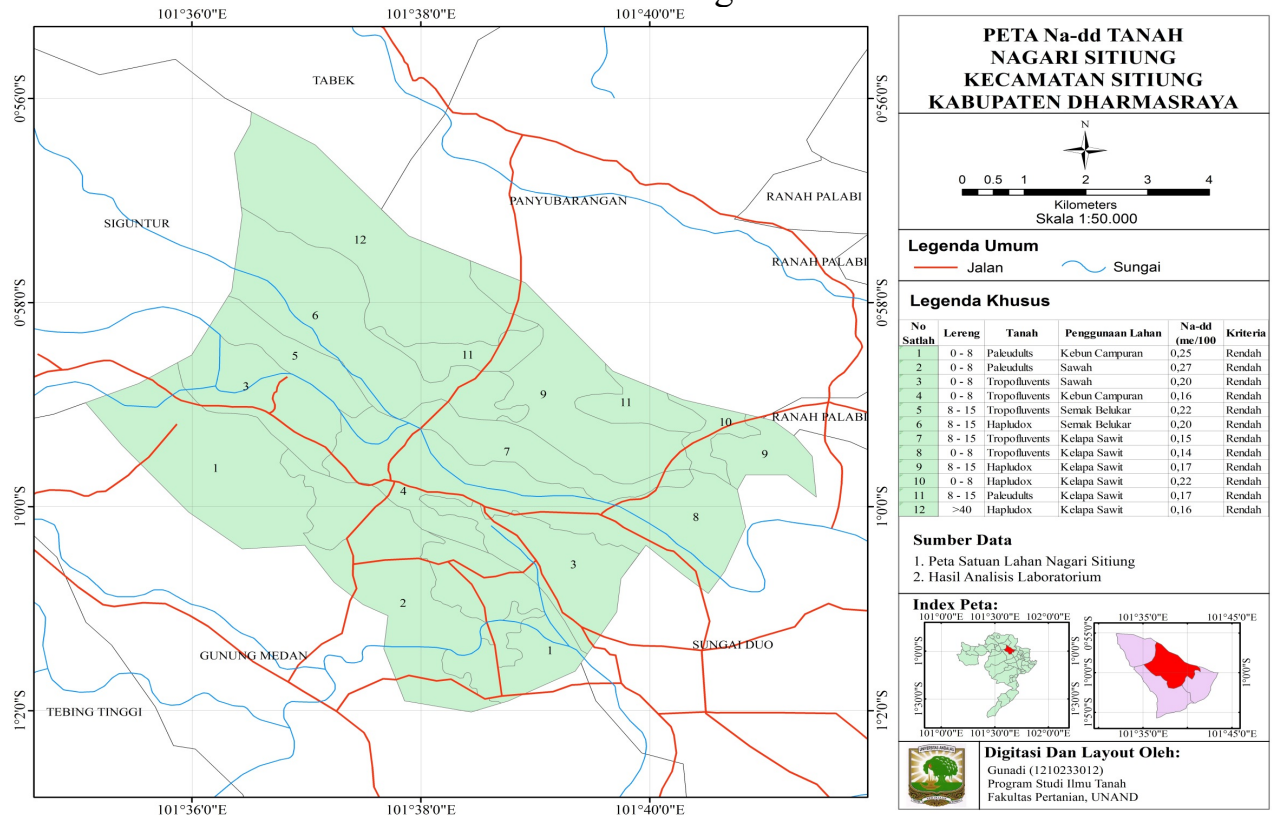

Gambar 11. Peta Na-dd Tanah

\section{KESIMPULAN}

Umumnya tanah di nagari Sitiung Kecamatan Sitiung Kabupaten Dharmasraya memiliki karakteristik sifat kimia tanah;nilai $\mathrm{pH}$ tertinggi 5,76 (agak masam) terdapat pada satuan lahan 3, dan nilai $\mathrm{pH}$ terendah 4,37 (sangat masam) terdapat pada satuan lahan 10. Nilai Al-dd tertinggi 9,72 satuan lahan 6, sedangkan nilai Al-dd terendah 0,92 terdapat pada satuan lahan 3. Selanjutnya, nilai Corganik tertinggi 3,12 (tinggi) terdapat pada satuan lahan 2, dan yang terendah 1,78 (rendah) pada satuan lahan 6. Kandungan $\mathrm{N}$-total semuanya berada pada kriteria sedang. Kandungan P-tersedia tertinggi 14,7 terdapat pada 10, dan yang terendah 7,93 (rendah) 
terdapat pada satuan lahan 4. Nilai KTK tertinggi 12,74 (rendah) terdapat pada satuan lahan 1, dan yang terendah 4,70 (sangat rendah) terdapat pada satuan lahan 7. Kandungan kation basa berada pada kriteria rendah sampai sedang.

\section{DAFTAR PUSTAKA}

BPS Dharmasraya. 2016. Kecamatan Sitiung dalam Angka 2016. Sikabau. 105 hal.

Bupati Dharmasraya. 2012. Peraturan Daerah Kabupaten Dharmasraya Nomor 10 Tahun 2012 tentang Rencana Tata Ruang Wilayah Kabupaten Dharmasraya Tahun 2011-2031. Pulau Punjung: Sekretaris Daerah.163hal.

Foth H.D., Ellis BG. 1997. Soil Fertility. $2^{\text {nd }}$ Ed. Boca Raton: Lewis Publisher. 212 hal

Hanafiah, K.A. 2005. Dasar-dasar Ilmu Tanah. Jakarta: PT Raja Grafindo Persada. 360 Hal.

Hardjowigeno, S. 2003. Klasifikasi Tanah dan Pedogenesis. Jakarta: Akademika Pressindo. 285 hal.

Litbang Pertanian. 2010. Perubahan Peruntukan Lahan Sawah Menjadi Lahan Perkebunan Kasus Irigasi Batang Hari. Jakarta: Balitbangtan. 186 hal.

Luki, U. 1999. Dasar-dasar Fisika Tanah Terapan I (Matrik Tanah). Padang: Jurusan Tanah Universitas Andalas. 158 hal.

Rykson, S., dan Sudadi, U. 2001. Tanah Sawah (Bahan Kuliah). Bogor: Institut Pertanian Bogor. 105 hal.
Salam, A.K. 2012. Ilmu Tanah Fundamental. Lampung: Global Madani Press. 362 hal.

Schmidt, F.H., dan Ferguson, J.H.A. 1951. Rainfall Type Based on the Wet and Dry Period Ratio for Indonesia with Western New Guinea. Jakarta: Verh Djawatan Mety dan Geofisik. 42 hal.

Sianturi, E.R. 2009. Survei dan pemetaan Ptersedia dan $\mathrm{pH}$ Tanah di Kebun Sukaluwei PT. NV Perimex Kec. Bangun Purba, Kab. Deli Serdang. [Skripsi] Departemen Ilmu Tanah Fakultas Pertanian Universitas Sumatera Utara. 33 hal.

Soewandita H. 2008. Studi Kesuburan Tanah dan Analisis Kesesuaian Lahan untuk Komoditas Tanaman Perkebunan di Kabupaten Bengkalis. Jurnal Sains dan Teknologi Indonesia Vol. 10 (2): 128133.133 hal.

Utomo, M., T. Sabrina, Sudarsono, J. Lumbranraja, B. Rusman, Wawan. 2016. Ilmu Tanah Dasar-dasar dan Pengelolaan. Jakarta: Prenadamedia Group. 433 hal.

Winarso, S. 2003. Kesuburan Tanah. Yogyakarta: Penerbit Gava Media. 269 hal.

Yanti, G. 2011. Pemantapan komposisi pupuk organik tithonia plus (POTP) untuk mengendalikan keracunan $\mathrm{Fe}$ dan mengurangi aplikasi pupuk buatan dalam peningkatan produksi padi pada sawah bukaan baru di Sitiung. Padang: [Tesis] Pascasarjana Universitas Andalas. 102 hal. 